\title{
Rapid recovery of gonadotroph function after down-regulation of receptors for GnRH in ewes
}

\author{
M. E. Crowder, R. D. Herring and T. M. Nett \\ Department of Physiology and Biophysics, College of Veterinary Medicine and Biomedical Sciences, \\ Colorado State University, Fort Collins, Colorado 80523, U.S.A.
}

\begin{abstract}
Summary. Several characteristics of the hypothalamo-hypophysial axis were examined after down-regulation of GnRH receptors and the desensitization which accompanies it in the ewe. Down-regulation of GnRH receptors, induced by i.v. infusion of GnRH $(2.5 \mu \mathrm{g} / \mathrm{h})$ for $24 \mathrm{~h}$, resulted in a $50 \%$ decrease in the number of receptors for GnRH at the end of the infusion period. The number of receptors for GnRH was restored to control values by $6 \mathrm{~h}$ after the infusion ended and remained stable at 12, 24, 48, 72 and $96 \mathrm{~h}$ after infusion. The amount of LH released in response to an i.v. injection of $100 \mu \mathrm{g}$ GnRH was reduced by $82 \%$ at the end of the infusion period, but there was no significant reduction in the GnRH-induced release of FSH. The GnRH-induced release of $\mathrm{LH}$ was restored by $12 \mathrm{~h}$ after the infusion ended; however, the amount of FSH released in response to $\mathrm{GnRH}$ was not different from control values at any time. A decrease in both the amplitude and frequency of endogenous pulses of LH was observed from 0 to $12 \mathrm{~h}$ after the end of the infusion period. At no time did the concentration of gonadotrophins in the pituitary change. These results demonstrate that replenishment of receptors for GnRH and recovery of the ability of the gonadotroph to release $\mathrm{LH}$ are associated events. However, the GnRH-induced release of FSH does not appear to be closely related to the number of GnRH receptors. We suggest that continuous exposure to GnRH may inhibit the hypothalamic pulse generator as well as the pituitary response to the pulse generator.
\end{abstract}

\section{Introduction}

In the pituitary of the ewe, down-regulation of receptors for GnRH is associated with desensitization, a decrease in the release of gonadotrophin in reponse to a subsequent injection of GnRH (Nett et al., 1981). This desensitization occurs despite the fact that pituitary concentrations of gonadotrophins are not lower in experimental than control animals (Nett et al., 1981). Desensitization has been observed after acute or chronic administration of $\mathrm{GnRH}$, or its analogues, in rats (Garner \& Blake, 1979; Clayton, 1982), sheep (Chakraborty et al., 1974) and women (Rabin \& McNeil, 1980; Heber \& Swerdloff, 1981). Because of the potential clinical uses of GnRH and its analogues in the treatment of infertility, acyclicity or in regulation of oestrus, it is particularly important to know the duration of desensitization after down-regulation of GnRH receptors by homologous hormone. The difficulties in achieving therapeutic success in the treatment of human infertility with GnRH and its analogues are well documented (for review see Labrie et al., 1981). A paradoxical antifertility effect is actually seen following treatment with these peptides in rats (Rivier et al., 1979), monkeys (Fraser, 1980; Fraser et al., 1980), men (Heber \& Swerdloff, 1980) and women (Koyama et al., 1978; Sheehan et al., 1982). The suppression of gonadotroph function may also be used to advantage in the treatment of various endocrine disorders or malignancies (Glodé et al., 1981; Santen et al., 1984). 
The following experiments were designed, therefore, to examine the replenishment of receptors for GnRH in the plasma membrane, recovery of pituitary responsiveness to GnRH, pituitary content of gonadotrophins and endogenous release of gonadotrophins after down-regulation of GnRH receptors by homologous hormone.

\section{Materials and Methods}

Three experiments were conducted to examine the hypothalamo-hypophysial axis after continuous exposure to $\mathrm{GnRH}$.

\section{Experiment 1}

Restoration of the number of receptors for $\mathrm{GnRH}$, the pituitary content of gonadotrophins and the response of the pituitary to $\mathrm{GnRH}$ were examined daily for 4 days after down-regulation of GnRH receptors.

Twenty-five ewes that had been ovariectomized for 60-80 days were fitted with jugular cannulae and placed in metabolic crates. Down-regulation of GnRH receptors was induced in these ewes by infusing GnRH $(2.5 \mu \mathrm{g} / \mathrm{h})$ for $24 \mathrm{~h}$ as previously described (Nett et al., 1981). Blood samples were obtained at $-1,-0 \cdot 5,0,2,4,6,8,23$ and $24 \mathrm{~h}$ of infusion. At the end of the infusion period, ewes were removed from metabolic crates and returned to indoor pens. To measure changes in the responsiveness of the pituitary to GnRH during recovery from down-regulation of GnRH receptors, $100 \mu \mathrm{g} \mathrm{GnRH}$ were injected i.v. at $0,24,48,72$ or $96 \mathrm{~h}$ (5 ewes/group) after the end of the infusion period. Blood samples were collected at 30 -min intervals from $1 \mathrm{~h}$ before the injection of $\mathrm{GnRH}$ until $5 \mathrm{~h}$ after injection. Five ewes that did not receive any infusion were also given $100 \mu \mathrm{g}$ GnRH and served as controls.

The infusion procedure was then repeated in 30 other ewes. These ewes (6/group) were killed with an overdose of pentobarbitone sodium at $0,24,48,72$ or $96 \mathrm{~h}$ after the end of infusion. Six ewes that did not receive any infusion were also killed and served as controls.

At slaughter, the pituitary was removed from each ewe and placed on ice. The connective tissue and posterior lobe were discarded and each anterior pituitary was weighed, frozen in liquid nitrogen and stored at $-70^{\circ} \mathrm{C}$ until assayed for $\mathrm{GnRH}$ receptors and content of gonadotrophins. This experiment was conducted in December 1981.

\section{Experiment 2}

After the results of Exp. 1 were obtained, Exp. 2 was conducted to evaluate the same characteristics at shorter times after the end of infusion. Infusions of GnRH were administered as described above to 30 ewes that had been ovariectomized for 3-4 weeks. Six ewes each were then given $100 \mu \mathrm{g}$ $\mathrm{GnRH}$ i.v. at 0,6 and $12 \mathrm{~h}$ after the end of infusion. Blood samples were collected at 30-min intervals from $1 \mathrm{~h}$ before to $5 \mathrm{~h}$ after injection of $\mathrm{GnRH}$. At each of those times, 4 ewes were also killed and their pituitaries were collected. An additional 10 ewes that did not receive any infusion served as controls. Six of these were given $100 \mu \mathrm{g}$ GnRH to assess pituitary responsiveness, and the remaining 4 ewes were killed and their pituitaries were collected. All pituitaries were stored as described for Exp. 1. This experiment was conducted in March and April 1983.

\section{Experiment 3}

This experiment was conducted to characterize the pulsatile nature of gonadotrophin release in addition to the GnRH-induced release of LH. Thirty-five ewes were given infusions of GnRH as described above. Blood samples were collected every $20 \mathrm{~min}$ for $1 \mathrm{~h}$ before the start of infusion and hourly from the time the infusion began until $6 \mathrm{~h}$ before the GnRH challenge injection was 
administered. Challenge injections of $\mathrm{GnRH}(100 \mu \mathrm{g})$ were given at $0,3,6,12$ and $24 \mathrm{~h}(5$ ewes/ group) after the end of the infusion period. Two control groups ( 5 ewes/group) were included in this experiment: one group was confined to metabolism crates and infused with saline, and the other group did not receive any treatment. Blood samples were obtained from both control groups identically to the infused ewes. The two groups of control ewes were given challenge injections at the end of the $24 \mathrm{~h}$ infusion period. For the $6 \mathrm{~h}$ before the challenge injection, blood samples were obtained at $10-\mathrm{min}$ intervals so that endogenous pulses of $\mathrm{LH}$ could be characterized. This experiment was conducted in April-June 1985.

\section{Assays}

The number of receptors for GnRH was measured in a partly purified membrane preparation of each individual pituitary by a standard curve technique described previously (Nett et al., 1981). Briefly, 50 and $100 \mu \mathrm{g}$ aliquants of partly purified membrane protein from each pituitary were incubated with $\left.0.2 \mathrm{M}-{ }^{125} \mathrm{I}\right] \mathrm{D}-\mathrm{Ala}^{6}-\mathrm{GnRH}-\mathrm{Pro}^{9}$-ethylamide (D-Ala ${ }^{6}-\mathrm{GnRH}-\mathrm{EA}$ ) in a total volume of $150 \mu \mathrm{l}$ buffer $\left(10 \mathrm{~mm}\right.$-Tris, $1 \mathrm{mM}-\mathrm{CaCl}_{2}, 0 \cdot 1 \% \mathrm{BSA}, \mathrm{pH} \mathrm{7.4)}$ for $6 \mathrm{~h}$ at $4^{\circ} \mathrm{C}$. At the end of incubation the membranes were diluted with $3 \mathrm{ml}$ ice-cold buffer and centrifuged for $10 \mathrm{~min}$ at $30000 \mathrm{~g}$. The supernatants were decanted and the radioactivity remaining in the pellet was quantified. The amount of $\left[{ }^{125} \mathrm{I}\right] \mathrm{D}-\mathrm{Ala}{ }^{6} \mathrm{GnRH}-\mathrm{EA}$ specifically bound to membranes from each pituitary was compared with a standard curve generated by incubating $0.2 \mathrm{nM}-\left[{ }^{125} \mathrm{I}\right] \mathrm{D}-\mathrm{Ala}{ }^{6}-\mathrm{GnRH}$-EA with increasing quantities $(3.1 \mu \mathrm{g}$ to $150 \mu \mathrm{g}$ protein) of a standard pituitary membrane preparation. The number of receptors in the standard pituitary membrane preparation was determined by Scatchard analysis (Scatchard, 1949) from data obtained by incubating various concentrations of $\left[{ }^{125} \mathrm{I}\right] \mathrm{D}-\mathrm{Ala}{ }^{6}-\mathrm{GnRH}-\mathrm{EA}(0 \cdot 1 \mathrm{nM}$ to $1 \mathrm{nM})$ with a constant amount of the standard pituitary membrane preparation. The number of receptors for $\mathrm{GnRH}$ per $\mu \mathrm{g}$ of standard pituitary membrane was then applied to the standard curve and used to calculate the number of receptors in the pituitaries of the experimental sheep. The interassay coefficient of variation was $6.4 \%$, and the assay detected as little as $1.5 \times 10^{-15} \mathrm{~mol}$ receptor. Over a period of 3 years, the number of receptors measured in aliquants of the standard membrane pool was $5.37 \pm 0.15 \times 10^{-16} \mathrm{~mol} \mu \mathrm{g}$ protein (mean \pm s.e.m.). The membranes had been kept frozen at $-70^{\circ} \mathrm{C}$.

The concentrations of LH (Niswender et al., 1969) and FSH (L'Hermite et al., 1972) were measured in pituitary cytosol and sera by radioimmunoassay. The interassay coefficient of variation for both assays was $<15 \%$. The assay sensitivity $(2 \times$ standard deviation from buffer control) was $50 \mathrm{pg}$ for $\mathrm{LH}$ and $3 \mathrm{ng}$ for FSH. Concentrations of gonadotrophin are reported in units of NIH-LH-S21 and NIH-FSH-S12.

\section{Statistical analysis}

Pituitary responsiveness to $\mathrm{GnRH}$ was determined by calculating the area under the response curve. Each LH and FSH response curve was graphed and the area above baseline was cut out and weighed.

Pulses of gonadotrophins were identified according to the criteria of Goodman \& Karsch (1980): (1) a peak must occur within two samples of a previous nadir, (2) the amplitude of the pulse must be greater than the sensitivity of the assay, and (3) the concentration of hormone at the peak must exceed the $95 \%$ confidence limits of the concentration of both the preceding and subsequent nadirs. Confidence limits for the hormone concentration in each sample were determined using the computer program of Duddleson et al. (1972). The sensitivity of the assay was defined as two standard deviations from buffer control. Amplitude of the pulse was defined as the concentration of hormone at the peak minus the concentration of hormone at the previous nadir.

Results were compared by analysis of variance. When variances between treatment groups were unequal, the results were subjected to $\log$ transformation before analysis of variance. Means for 
treatment and control groups were compared according to Dunnett's procedure (Steel \& Torrie, 1960).

There were no differences between the untreated and saline-infused control groups in Exp. 3 with regard to any of the values measured. Therefore, these 2 control groups were combined for the final analysis of data.

Each experiment was analysed separately. Since there were no differences between identical treatment groups in different experiments, all data were combined for a final analysis. When appropriate, the combined data of the experiments are presented for clarity.

\section{Results}

As expected, infusion of GnRH resulted in increases in serum concentrations of LH and FSH that were maximal $2 \mathrm{~h}$ after the initiation of infusion. Concentrations of LH and FSH in serum then declined, reaching a concentration similar to the pre-infusion baseline by $6 \mathrm{~h}(\mathrm{FSH})$ and $23 \mathrm{~h}(\mathrm{LH})$. The concentration of LH in serum remained at baseline in the absence of exogenous GnRH for $96 \mathrm{~h}$ after the infusion was stopped. In contrast, the concentration of FSH in serum continued to decline during the last part of the infusion period, and gradually returned to the preinfusion baseline during the next $96 \mathrm{~h}$. Data from Exp. 1 are presented in Fig. 1.

The number of receptors for GnRH was reduced $(P<0.05)$ by $50 \%$ at the end of the infusion period compared to the number of receptors in ewes not receiving infusions (Fig. 2). By $6 \mathrm{~h}$ after the end of infusion, the number of $\mathrm{GnRH}$ receptors was not different from that measured in control animals. The number of receptors remained stable from 6 to $96 \mathrm{~h}$ after the infusion period ended.

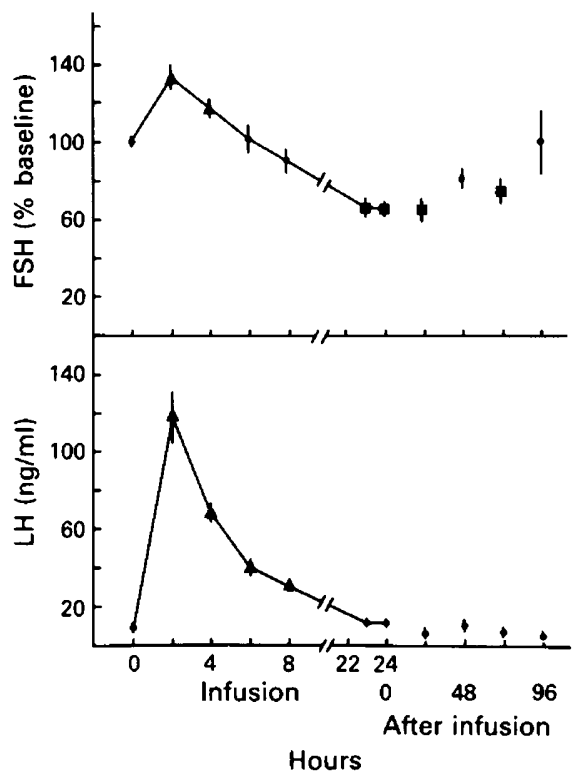

Fig. 1. Concentrations of $\mathrm{LH}$ and FSH (mean \pm s.e.m.) in serum during a 24-h infusion of GnRH and 0, 24, 48, 72 and $96 \mathrm{~h}$ after the end of the infusion period (Exp. 1, 5 ewes/group). Because of the variation in concentrations of FSH between animals, data are presented as \% of the mean of pre-infusion samples. $\boldsymbol{\Delta}$, values significantly greater than baseline $(P<0.05)$. $\mathbf{Q}$, values significantly lower than baseline $(P<0.05)$. 


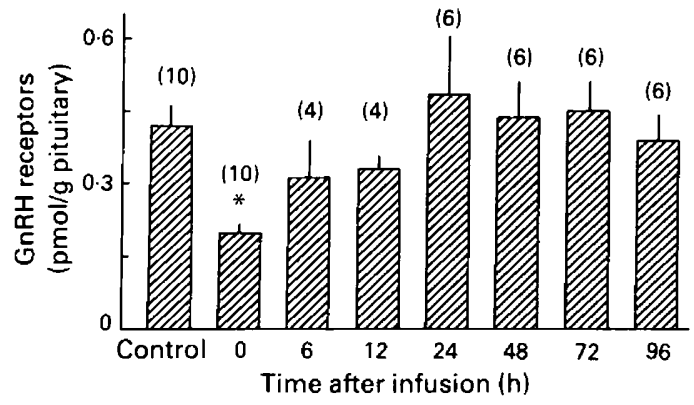

Fig. 2. The numbers of GnRH receptors (mean \pm s.e.m.) in the anterior pituitaries of ewes after down-regulation of GnRH receptors induced by a 24-h infusion of GnRH (Exps 1 \& 2). The control group did not receive an infusion. Values are mean \pm s.e.m. for the no. of ewes given in parentheses. ${ }^{*} P<0.05$ compared with control value.

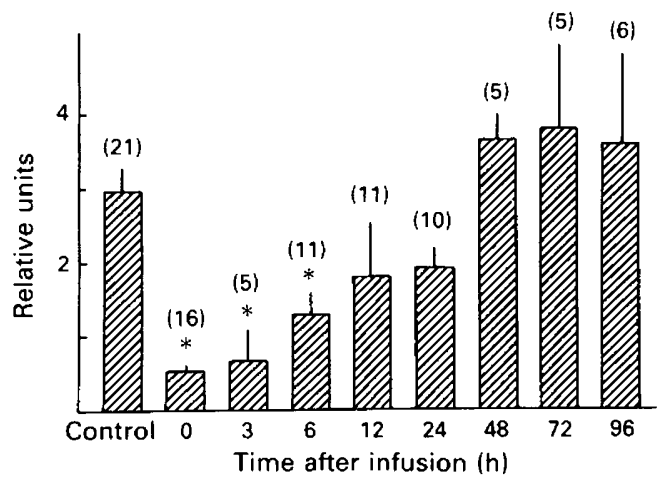

Fig. 3. The area under the curve of the GnRH-induced release of LH (mean \pm s.e.m. for the no. of ewes indicated in parentheses) after down-regulation of GnRH receptors induced by a 24-h infusion of GnRH (Exps 1, 2, \& 3). ${ }^{*} P<0.05$ compared with control value.

Initially, the GnRH-induced release of $\mathrm{LH}$ followed a pattern similar to the number of GnRH receptors, in that there was an $82 \%$ reduction $(P<0.05)$ in the amount of LH released in response to injection of GnRH at the end of the infusion period (Fig. 3). However, unlike the number of GnRH receptors, the GnRH-induced release of LH remained suppressed at $3 \mathrm{~h}$ and $6 \mathrm{~h}$ after the end of infusion. LH responsiveness did not differ from control from 12 to $96 \mathrm{~h}$ after infusion was stopped.

In contrast to the GnRH-induced release of $\mathrm{LH}$, the GnRH-induced release of FSH in treated animals was not different from that in control animals at any time after the end of the infusion period (data not shown).

Both the frequency (number of pulses in $6 \mathrm{~h}$ ) and amplitude of pulses of LH were reduced, compared to control ewes, in ewes bled 0 to $6 \mathrm{~h}$ after the end of infusion and 6-12 $\mathrm{h}$ after the end of infusion (Table 1). The amplitude of LH pulses was still reduced in ewes bled from 18 to $24 \mathrm{~h}$ after the end of the infusion period, although pulse frequency had returned to control values. The mean amplitude of $\mathrm{LH}$ pulses was also reduced in the -3 to $+3 \mathrm{~h}$ group. This reduction was not significant when tested with Dunnett's procedure, however, because there were few observed pulses. FSH did not appear to be released in a pulsatile pattern in any ewe.

Concentrations of LH and FSH in pituitary cytosol were unchanged by treatment throughout the period of study, and did not differ from concentrations in control ewes (Fig. 4). 
Table 1. Frequency and amplitude of pulses of LH observed in ewes (5/treatment group, 10/control group) after infusion of GnRH

\begin{tabular}{|c|c|c|c|c|c|c|}
\hline & \multirow[b]{2}{*}{ Control } & \multicolumn{5}{|c|}{ Time relative to end of infusion } \\
\hline & & -6 to $0 h$ & -3 to $+3 h$ & 0 to $+6 h$ & +6 to $+12 \mathrm{~h}$ & +18 to $+24 h$ \\
\hline $\begin{array}{l}\text { Frequency } \\
\text { (no. of pulses } \\
\text { in } 6 \mathrm{~h} \text { ) }\end{array}$ & $7.07 \pm 0.07$ & $4 \cdot 8 \pm 1 \cdot 0$ & $3.6 \pm 1.0$ & $3.0 \pm 0.9^{*}$ & $2.2 \pm 0.7^{*}$ & $7.6 \pm 0.5$ \\
\hline $\begin{array}{l}\text { Amplitude } \\
\text { (ng/ml) }\end{array}$ & $8.46 \pm 1.06$ & $10 \cdot 30 \pm 2 \cdot 96$ & $3.33 \pm 0.99$ & $1.55 \pm 0.24^{*}$ & $1 \cdot 08 \pm 0 \cdot 13^{*}$ & $4 \cdot 52 \pm 1 \cdot 11^{*}$ \\
\hline
\end{tabular}

Values are mean \pm s.e.m.

*Different from control $(P<0.05)$ (Dunnett's test with unequal number of observations).

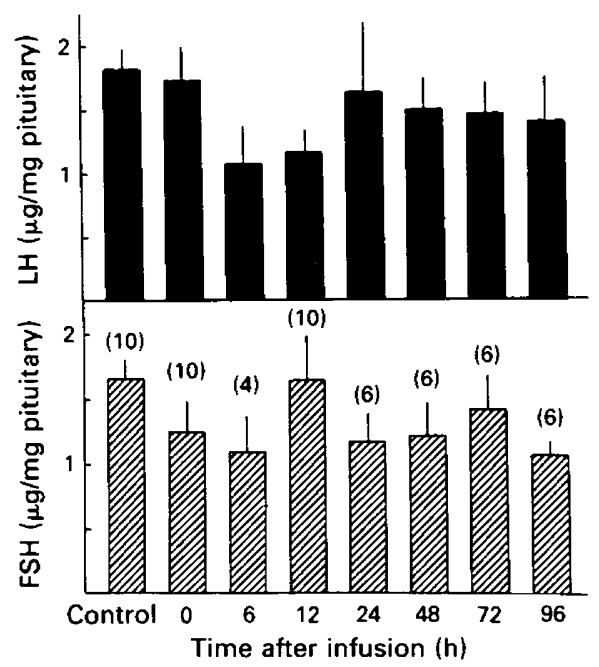

Fig. 4. Concentrations of LH and FSH (mean \pm s.e.m. for the no. of ewes indicated in parentheses) in the anterior pituitaries of ewes after down-regulation of GnRH receptors induced by a 24 -h infusion.

\section{Discussion}

The down-regulation of receptors for GnRH observed at the end of the infusion of GnRH is similar to that described previously (Nett et al., 1981). It is unlikely that this decrease in measurable receptors is due to occupancy of the receptor sites because of the rapid dissociation of native GnRH from its receptor (Wagner et al., 1979). Any native hormone bound to the GnRH receptor would therefore dissociate and be discarded during preparation of the membrane fraction to be used for assay. In fact, in pituitaries collected from ewes after a 16-h infusion of GnRH, only $8 \pm 2$ fmol GnRH could be extracted with acidified methanol (Nett \& Adams, 1977) from the membrane fraction (Nett et al., 1981). The number of receptors measured in these same membranes was $198 \pm 50 \mathrm{fmol}$. Considering the affinity of the receptor for $\mathrm{GnRH}\left(K_{\mathrm{a}}=7 \times 10^{9} \mathrm{M}^{-1}\right)$, it is probable that none of the hormone would actually be bound to receptor.

The increase in the number of hypophysial receptors for GnRH to preinfusion values after down-regulation is notably rapid. In rat testis (Conti et al., 1977; Hsueh et al., 1977; Saez et al., 1978) and rat corpora lutea (Conti et al., 1977), receptors for LH returned to control levels over a 
period of 5-10 days after down-regulation induced by hCG. In sheep corpora lutea in which the LH receptors had been down-regulated by $\mathrm{LH}$, recovery of receptors was complete within $48 \mathrm{~h}$ (Suter $e t$ al., 1980).

In cultured pituitary cells from rats, down-regulation of receptors for GnRH occurred $1 \mathrm{~h}$ after administration of GnRH (Loumaye \& Catt, 1983). The number of receptors for GnRH returned to the control value by $5 \mathrm{~h}$ and then increased to $120-140 \%$ of control value by $10 \mathrm{~h}$. In contrast to the present study, these authors did not see a decrease in the release of LH associated with downregulation of GnRH receptors. However, LH was measured in aliquants of media withdrawn at intervals and thus represented accumulation of $\mathrm{LH}$ rather than GnRH-stimulated release of $\mathrm{LH}$ (Loumaye \& Catt, 1983).

The decrease in the number of receptors for GnRH after infusion of GnRH was accompanied by a reduction in the amount of $\mathrm{LH}$ released by $\mathrm{GnRH}$ stimulation. Similarly, in rat pituitary cells in culture, GnRH induced a $70 \%$ reduction in the number of receptors for $\mathrm{GnRH}$ and a $93 \%$ decrease in the ability of the cells to release LH (Hazum \& Schwartz, 1984). The reduction in GnRH-induced release of $\mathrm{LH}$ at the end of the infusion period $(0 \mathrm{~h})$ in the present study can probably be attributed to down-regulation of $\mathrm{GnRH}$ receptors and not to depletion of pituitary stores of LH since at no time was there a significant decrease in the concentration of gonadotrophins in the pituitary. However, Bremner \& Paulsen (1974) have reported that there are two pools of LH in the pituitary: a readily releasable pool and a non-releasable pool. During a GnRH infusion the readily releasable pool of LH is rapidly depleted (Bremner et al., 1976, 1980; de Koning et al., 1976). LH stored in the non-releasable pool must then be transferred to the releasable pool, a step which is partly blocked by actinomycin D (Vilchez-Martinez et al., 1976). At present we have no indication of how rapidly $\mathrm{LH}$ can be changed from a non-releasable form to a releasable form. Therefore, although pituitary content of $\mathrm{LH}$ did not decline overall, the portion of $\mathrm{LH}$ in a releasable form may be reduced for some time after the end of the infusion.

Although the number of GnRH receptors had increased to control values by $6 \mathrm{~h}$ after the end of infusion, the GnRH-induced release of LH remained suppressed until $12 \mathrm{~h}$. Similarly, Smith et al. (1983) observed that, in rat pituitary cells in culture, the number of GnRH receptors increased to $150 \%$ of control value at $12 \mathrm{~h}$ after exposure to $\mathrm{GnRH}$, but the GnRH-induced release of $\mathrm{LH}$ remained depressed. These results suggest that, while down-regulation of receptors may account for the initial reduction in tissue responsiveness, some post-receptor mechanism may also be involved in desensitization.

In contrast to $\mathrm{LH}$, the pattern of FSH release in response to $\mathrm{GnRH}$ does not appear to be closely associated with the number of GnRH receptors, since at no time was the GnRH-induced release of FSH significantly lower than the control value. Basal concentrations of LH and FSH were also divergent. While basal concentrations of $\mathrm{LH}$ in serum were similar to the pre-infusion baseline each day after the infusion ended, basal concentrations of FSH were depressed until $96 \mathrm{~h}$ after the end of infusion. The absence of ovarian steroids which could selectively modulate secretion of the two gonadotrophins, and the observation that concentrations of LH and FSH in the pituitary did not change during the experiment make it difficult to explain the difference in secretion of the two gonadotrophins. It is possible that in the ovariectomized ewe, which lacks inhibin, FSH secretion is maximal because it is no longer selectively inhibited. This may explain why there was no suppression of the GnRH-induced release of FSH, but it does not provide a reason for the depression in basal concentrations of FSH. In other studies, altering the frequency of pulsatile administration of $\mathrm{GnRH}$ to ovariectomized rhesus monkeys bearing hypothalamic lesions altered the patterns of gonadotrophin secretion (Knobil, 1981). Frequencies greater than 1 pulse/h resulted in diminished secretion of both gonadotrophins, while a frequency of $1 \mathrm{pulse} / 3 \mathrm{~h}$ had no effect on LH secretion, but resulted in increased release of FSH. These studies prompted us to examine the pulsatile release of $\mathrm{LH}$ after continuous infusion of GnRH.

In the present study we noted a decrease in the frequency of endogenous pulses of $\mathrm{LH}$ between 0 and $12 \mathrm{~h}$ after the end of the infusion. When both GnRH and LH have been measured, pulses of 
LH in serum have always occurred in synchrony with or slightly after pulses of GnRH (Clarke \& Cummins, 1982). Therefore, the decrease in LH pulse frequency observed in this study is due presumably to a reduction in the frequency of hypothalamic pulses of GnRH. Our data show a correlation between this presumptive decrease in $\mathrm{GnRH}$ pulse frequency and a decrease in GnRHinduced release of $\mathrm{LH}$, but not GnRH-induced release of FSH. This provides further support for the concept that while GnRH may regulate the potential of the gonadotroph to release LH, it may not be the only regulator of FSH release. In fact, antiserum to GnRH abolished pulsatile secretion of $\mathrm{LH}$ in castrated rats but had no effect on the number of FSH pulses (Culler \& Negro-Villar, 1986).

From 0 to $24 \mathrm{~h}$ after the end of the infusion period, a decrease in the amplitude of LH pulses was also observed. Serum concentrations of GnRH were not measured in this study, so it was not possible to determine whether the amplitude of hypothalamic pulses of $\mathrm{GnRH}$ was also reduced. However, because the number of GnRH receptors and the ability of GnRH to release LH had been restored to control values by $6 \mathrm{~h}$ and $12 \mathrm{~h}$, respectively, it appears that neither the concentration of GnRH receptors, a post-receptor defect, nor a deficiency in the releasable pool of $\mathrm{LH}$ could be limiting the response of the pituitary to $\mathrm{GnRH}$ at $24 \mathrm{~h}$ after the end of the infusion. It seems likely that the amplitude of endogenous pulses of GnRH may be suppressed for $24 \mathrm{~h}$ after the end of the GnRH infusion period.

In rats, the stress of immobilisation has been shown to inhibit the increase in the number of GnRH receptors and the release of $\mathrm{LH}$ which are induced by GnRH (Garcia et al., 1985). There are no reports of such an effect in sheep. In the present study, we did not observe any differences between the uninfused control ewes and the saline-infused control ewes with regard to any characteristic measured. It is therefore unlikely that the down-regulation of GnRH receptors and the decreases in amplitude and frequency of $\mathrm{LH}$ pulses were due to stress.

From these studies we conclude that down-regulation of GnRH receptors by native hormone is a short-lived phenomenon in the pituitary of the ewe. Desensitization of LH responsiveness, but not FSH responsiveness, accompanies down-regulation. This desensitization is unrelated to pituitary content of $\mathrm{LH}$, and probably involves a post-receptor defect since the concentration of $\mathrm{GnRH}$ receptors was restored to control values before the restoration of responsiveness to GnRH. The frequency and amplitude of LH pulses, and presumably GnRH pulses, was also suppressed by continuous exposure to GnRH. The role of those endogenous pulses in regulation of the number of $\mathrm{GnRH}$ receptors and pituitary responsiveness to $\mathrm{GnRH}$ is unclear.

This research was supported by NIH grants HD 07841, HD 13568 and a grant from the Colorado State Experiment Station.

\section{References}

Bremner, W.J. \& Paulsen, C.A. (1974) Two pools of luteinizing hormone in the human pituitary: evidence from constant administration of luteinizing hormonereleasing hormone. J. clin. Endocr. Metab. 39, $811-815$.

Bremner, W.J., Findlay, J.K., Cumming, I.A., Hudson, B. \& de Kretser, D.M. (1976) Pituitary-testicular responses in rams to prolonged infusions of luteinizing hormone-releasing hormone (LHRH). Biol. Reprod. $15,14 \mathrm{I}-146$.

Bremner, W.J., Findlay, J.K., Lee, V.W.K., de Kretser, D.M. \& Cumming, I.A. (1980) Feedback effects of the testis on pituitary responsiveness to luteinizing hormone-releasing hormone infusions in the ram. Endocrinology 106, 329-336.

Chakraborty, P.K., Adams, T.E., Tarnavsky, G.K. \& Reeves, J.J. (1974) Serum and pituitary LH concen- trations in ewes infused with LH-RH/FSH-RH. $J$. Anim. Sci. 39, 1150-1157.

Clarke, I.J. \& Cummins, J.T. (1982) The temporal relationship between gonadotropin releasing hormone (GnRH) and luteinizing hormone (LH) secretion in ovariectomized ewes. Endocrinology 111, 1737-1739.

Clayton, R.N. (1982) Gonadotropin-releasing hormone modulation of its own pituitary receptors: evidence for biphasic regulation. Endocrinology 111, 152-161.

Conti, M., Harwood, J.P., Dufau, M.L. \& Catt, K.J. (1977) Regulation of luteinizing hormone receptors and adenylate cyclase activity by gonadotrophin in the rat ovary. Molec. Pharmacol. 13, 1024-1032.

Culler, M.D. \& Negro-Villar, A. (1986) Evidence that pulsatile follicle-stimulating hormone secretion is independent of endogenous luteinizing hormonereleasing hormone. Endocrinology 118, 609-612. 
de Koning, J., van Dieten, J.A.M.J. \& van Rees, G.P. (1976) LH-RH dependent synthesis of protein necessary for LH release from rat pituitary glands in vitro. Molec. cell. Endocrinol. 5, 151-160.

Duddleson, W.G., Midgley, A.R., Jr. \& Niswender, G.D. (1972) Computer program sequence for analysis and summary of radioimmunoassay data. Comp. Biomed. Res. 5, 205-217.

Fraser, H.M. (1980) Effect of chronic treatment with an agonist of luteinizing hormone releasing hormone for one year in the female stumptailed monkey (Macaca arctoides). Endocrinology 106, Suppl. 1, 236 Abstr.

Fraser, H.M., Laird, N.C. \& Blakeley, D.M. (1980) Decreased pituitary responsiveness and inhibition of the luteinizing hormone surge and ovulation in the stumptailed monkey (Macaca arctoides) by chronic treatment with an agonist of luteinizing hormonereleasing hormone. Endocrinology 106, 452-457.

Garcia, A., Herbon, L., Barkan, A., Papavasiliou, S. \& Marshall, J. (1985) Hyperprolactinemia inhibits gonadotropin-releasing hormone (GnRH) stimulation of the number of pituitary $\mathrm{GnRH}$ receptors. Endocrinology 117, 954-959.

Garner, L.L. \& Blake, C.A. (1979) Morphological correlates for LHRH self-priming and anterior pituitary gland refractoriness to LHRH in proestrous rats: an immunocytochemical study. Biol. Reprod. 20, 1055-1066.

Glodé, L.M., Robinson, J. \& Gould, S.F. (1981) Protection from cyclophosphamide induced testicular damage by an analogue of gonadotropin releasing hormone. Lancet i, 1132-1134.

Goodman, R.L. \& Karsch, F.J. (1980) Pulsatile secretion of luteinizing hormone: differential suppression by ovarian steroids. Endocrinology 107, 1286-1290.

Hazum, E. \& Schwartz, I. (1984) Photoaffinity labeling of gonadotropin releasing hormone receptors in control and desensitized pituitary cells. Biochem. Biophys. Res. Commun. 125, 532-538.

Heber, D. \& Swerdloff, R.S. (1980) Male contraception: synergism of gonadotropin-releasing hormone analog and testosterone in suppressing gonadotropin. Science, N.Y. 209, 936-938.

Heber, D. \& Swerdloff, R.S. (1981) Down-regulation of pituitary gonadotropin secretion in postmenopausal females by continuous gonadotropin-releasing hormone administration. J. clin. Endocr. Metab. 52, 171-172.

Hsueh, A.J.W., Dufau, M.L. \& Catt, K.J. (1977) Gonadotropin-induced regulation of luteinizing hormone receptors and desensitization of testicular $3^{\prime}: 5^{\prime}$-cyclic AMP and testicular response. Proc. natn. Acad. Sci. U.S.A. 74, 592-595.

Knobil, E. (1981) Patterns of hypophysiotropic signals and gonadotropin secretion in the rhesus monkey. Biol. Reprod. 24, 44-49.

Koyama, T., Onkura, T., Kumasaka, T. \& Salto, M. (1978) Effect of postovulatory treatment with a luteinizing hormone-releasing hormone analog on the plasma level of progesterone in women. Fertil. Steril. 30, 549-552.

Labrie, F., Belanger, A., Seguin, C., Cusan, L., Pelletier, G., Lefebvre, F.-A., Kelly, P.A., Ferland, L., Reeves, J.J., Lemay, A. \& Raynaud, J.-P. (1981) Inhibition of testicular and ovarian functions of LHRH agonists. In Bioregulators of Reproduction, pp. 305-341. Eds G. Jagiello \& H. J. Vogel. Academic Press, New York.
L'Hermite, M., Niswender, G.D., Reichert, L.E., Jr \& Midgley, A.R., Jr (1972) Serum follicle-stimulating hormone in sheep as measured by radioimmunoassay. Biol. Reprod. 6, 325-332.

Loumaye, E. \& Catt, K.J. (1983) Agonist-induced regulation of pituitary receptors for gonadotropinreleasing hormone. J. biol. Chem. 258, 12002-12009.

Nett, T.M. \& Adams, T.E. (1977) Further studies on the radioimmunoassay of gonadotropin-releasing hormone: effect of radioiodination, antiserum and unextracted serum on levels of immunoreactivity in serum Endocrinology 101, 1135-1144.

Nett, T.M., Crowder, M.E., Moss, G.E. \& Duello, T.M. (1981) GnRH-receptor interaction. V. Downregulation of pituitary receptors for $\mathrm{GnRH}$ in ovariectomized ewes by infusion of homologous hormone. Biol. Reprod. 24, 1145-1155.

Niswender, G.D., Reichert, L.E., Midgley, A.R., Jr \& Nalbandov, A.V. (1969) Radioimmunoassay for bovine and ovine luteinizing hormone. Endocrinology 84 , $1166-1173$.

Rabin, D. \& McNeil, L.W. (1980) Pituitary and gonadal desensitization after continuous luteinizing hormonereleasing hormone infusion in normal females. J. clin. Endocr. Metab. 51, 873-876.

Rivier, C., Rivier, J. \& Vale, W. (1979) Chronic effects of [D-Trp ${ }^{6}$, Pro ${ }^{9}$-NEt] luteinizing hormone-releasing factor on reproductive processes in the male rat. Endocrinology 105, 1191-1201.

Saez, J.M., Haour, F., Tell, G.P.E., Gallet, D. \& Sanchez, P. (1978) Human chorionic gonadotropin-induced Leydig cell refractoriness to gonadotropin stimulation. Molec. Pharmacol. 14, 1054-1062.

Santen, R.J., Demers, L.M., Max, D.T., Smith, J., Stein, B.S. \& Globe, L.M. (1984) Long-term effects of administration of a gonadotropin-releasing hormone superagonist analog in men with prostatic carcinoma. J. clin. Endocr. Metab. 58, 397-400.

Scatchard, G. (1949) The attraction of proteins for small molecules and ions. Ann. N.Y. Acad. Sci. 51, 660-672.

Sheehan, K.L., Casper, R.F. \& Yen, S.S.C. (1982) Luteal phase defects induced by an agonist of luteinizing hormone-releasing factor: a model for fertility control. Science, N.Y. 215, 170-172.

Smith, M.A., Perrin, M.H. \& Vale, W.W. (1983) Desensitization of cultured pituitary cells to gonadotropinreleasing hormone: evidence for a post-receptor mechanism. Molec. cell. Endocr. 30, 85-96.

Steel, R.G.D. \& Torrie, J.H. (1960) Principles and Procedures of Statistics, pp. 111-114. McGraw-Hill, New York.

Suter, D.E., Fletcher, P.W., Sluss, P.M., Reichert, L.E. Jr \& Niswender, G.D. (1980) Alterations in the number of ovine luteal receptors for $\mathrm{LH}$ and progesterone secretion induced by homologous hormone. Biol. Reprod. 22, 205-210.

Vilchez-Martinez, J.A., Arimura, A. \& Schally, A.V. (1976) Effect of actinomycin D on the pituitary response to LH-RH. Acta endocr., Copenh. 81, 73 81.

Wagner, T.O.F., Adams, T.E. \& Nett, T.M. (1979) GnRH interaction with anterior pituitary. I. Determination of the affinity and number of receptors for $\mathrm{GnRH}$ in ovine anterior pituitary. Biol. Reprod. 20, 140-149. 